\title{
ENVIRONMENTAL TRIAL OF PEA BREEDING ACESSIONS
}

Shevchenko L.M. ${ }^{1}$, Vasylenko A.O. ${ }^{1}$, Sichkar V.I. ${ }^{2}$, Vus N.O. ${ }^{3}$, Bezuglyi I.M. ${ }^{1}$, Solomonov R.V. ${ }^{2}$, Shtelma A.M. ${ }^{1}$, Glyantsev A.V. ${ }^{1}$

${ }^{1}$ Plant Production Institute named after V.Ya. Yuriev of NAAN, Ukraine

${ }^{2}$ Odesa State Agricultural Research Station, Ukraine

${ }^{3}$ Kharkiv National University nd a V.N. Karazin, Ukraine

The results of an environmental trial of pea cultivars and breeding lines conducted in the Odeska and Kharkivska Oblasts are presented. In the trial years, the hydrothermal mode during the vegetation period was extremely various, which helped to fulfill the potential yield and evaluate the yield under stressful conditions both at Odesa State Experimental Station and at the Plant Production Institute NAAS. The obtained results indicate different levels of adaptation to agroclimatic conditions. We concluded that environmental trials remain an effective tool for evaluating pea breeding material and selection of accessions with the maximum fulfillment of the genetic potential.

Key words: pea, variety, yield, environmental testing, genotypic effect, regression coefficient, stability

Introduction. Given the current trend in European agriculture, measures aimed at preservation of soils, organic and environmentally friendly production and ensuring sustainable production are impossible without legumes. In Ukraine, pea is one of the most common legumes, which is grown in all zones. To increase the breeding effectiveness, it is necessary to test both the existing cultivars varieties and new breeding material under various conditions.

Literature review. Assessment of an environment as a background for selections is an important objective in raising the breeding effectiveness. This is also a mandatory factor for adequate assessment of genotypes and prevention of loss of valuable breeding material as a result of the genotype-environment interactions [1]. Shektybaieva et al. noted that the breeding effectiveness could be increased by testing new hybrids of different quality at different climatic trial sites, where stressors limiting yields are quite frequent [2].

As AA Detsyna pointed out, environmental trials of new promising cultivars are extremely essential, because they increase the effectiveness of the evaluation of new material for basic valuable economic characteristics. It also allows objective assessing the environmental stability and distinguishing a cultivar with stable performance. Harmonized trials mean an opportunity to obtain objective and unified results [3].

Currently, environmental trials are conducted with a practical purpose - to assess cultivars of different eco-geographical origin for suitability for cultivation in new conditions or by new technologies. Thus, Tukulbaieva et al. assessed spring rapeseed cultivars for the conditions in the Republic of Kazakhstan, because rapeseed is widely grown on farms of the Kostanay and South Kazakhstan Regions. Accessions were evaluated for yield, oil content, growing period, resistance to diseases and pests, and ease of production [4]. As Sidoryk et al. reported, the lack of adaptive soybean cultivars hindered its widespread introduction in North Kazakhstan. Environmental trials of soybean cultivars of different eco-geographical origin (bred at the Kazakh Research Institute of Agriculture and Plant Growing and bought from a Dutch company [Matrix]) were conducted, and they showed that sortseason cultivars with a growing period of 90-100 days were the most suitable [5].

Within the "Green Economy" framework in the Republic of Kazakhstan, the gradual reduction in unprofitable and water-intensive crops with their replacement by less water-demanding

(C) L.M. Shevchenko, A.O. Vasylenko, V.I. Sichkar, N.O. Vus, I.M. Bezuglyi, R.V. Solomonov, A.M. Shtelma, A.V. Glyantsev. 2021.

ISSN 1026-9959. Селекція і насінництво. 2021. Випуск 119 
vegetables, fodder and oil crops is one of the three lines of the implementation of a water-saving program in the agriculture. Thus, one of the practical results is barley sowing in rice bays, next to rice fields. This sowing design has a positive effect on grain filling due to raising the groundwater level during, when water is supplied for irrigation. A trial of 60 barley and oat cultivars of different eco-geographical origin was conducted on saline soils of the Aral Sea Region (Kyzylorda Region). It showed that in such a specific arid climate short-season genotypes that optimally used natural water reserves in soil and completed grain filling before the summer drought onset were of great interest [6].

Environmental trial assessments are condition-driven. Thus, in the arid central zone of the Republic of Kalmykia, spring barley cultivars were tested for drought tolerance and compared the yields from winter and spring barley in drastically arid conditions of the Kalmyk steppe [7]. The system of selections in complex hybrid populations carried out under various environmental conditions proved to be effective for clover. Due to this approach, promising populations combining drought resistance with high forage and seed productivity were identified [8].

Environmental trials are aimed not only at identification of high-yielding, stress-resistant accessions. Assessment of the stability of yields or of other studied traits is another important objective. V.V. Mameiev found that winter wheat cultivars that gave higher yields with the least year-to-year fluctuations in the yield were the most valuable for grain producers. Calculations of linear regression, which characterizes the environmental plasticity of an accession, and of the standard deviation from the regression line, which is an indicator of its stability, performed according to S.A. Eberhart and W.A. Russell's mathematical model are objective and allow for evaluation of both a small and a large sample of accessions [9]. This mathematical model has proven its effectiveness on many crops $[10,11,12]$.

Our purpose was to determine the information capacity and adequacy of the environment trial sites for pea breeding material and selection of the "ideal" genotype.

Materials and methods. Pea accessions were grown at Odesa State Experimental Station (OSES; Khlibodarske village, Odeskyi Raion, Odeska Oblast; 46²9'05" N latitude, 30³5'31" E longitude) and in the experimental field of the Plant Production Institute named after V.Ya. Yuriev (PPI NAAS) (Elitne village, Kharkivskyi Raion, Kharkivska Oblast (49 59'31" N latitude, $36^{\circ} 26^{\prime} 55^{\prime \prime}$ E longitude).

The environmental parameters in the study sites differ significantly: OSES is in the southsteppe subzone of the steppe, and PPI NAAS is in the eastern forest-steppe.

The breeding material in the experiments was represented by cultivars bred at the PPI nd.a. V.Ya. Yuriev (Tsarevych, Oplot, Otaman, Metsenat, Korvet, Haiduk, and Malakhit) and ten breeding lines (SL 11-129, SL 11-213, SL 11-55, SL 11-58, SL 10-37, SL 11-32, SL 10-132, SL 09-118, SL 11-166, and SL 11-176). In addition there was one cultivar (Svit) bred at the Plant Breeding and Genetics Institute. All the cultivars are leafless, semi-dwarf, mid-ripening, except for Tsarevych (mid-early).

The field experiments were carried out in accordance with the methods of field experimentation [13], using the conventional pea growing technology. The seeding rate was 1.2 million germinable seeds/ha; the plot area was $10 \mathrm{~m}^{2}$.

To evaluate the accessions for the variability in different environments, we used a regression model developed by S.A. Eberhart and W.A. Russel, where the regression coefficient is an indicator of the genotype-environment interaction. This model is included in "Guidelines for Environmental Trials of Corn" [14].

The environment effect (dk) was calculated, as AV Kilchevskiy et al. specified. [15].

Results and discussion. In 2018-2020, the precipitation was short and extremely inefficient on the territory of Odesa State Experimental Station during the pea growing period. In 2018 and 2020, pea plants experienced a significant water deficit from the very beginning of the growing period. In 2019, the spring moisture reserves and moderate temperatures from April to May allowed pea plants to form a strong vegetative mass until the anthesis onset, which had a positive effect on the yield. The hydrothermal mode during the pea growing period in the Kharkivska Oblast in the study years was not optimal or favorable, as evidenced by the average yield in the experiment. (Table 2).

Analysis of the year condition index $\left(d_{k}\right)$ showed that the study years differed significantly 
Condition index and the coefficient of variation for the yield

\begin{tabular}{ccccc}
\hline \multirow{2}{*}{ Year } & \multicolumn{3}{c}{$d_{k}{ }^{*}$} & \multicolumn{2}{c}{$\mathrm{V}, \%$} \\
\cline { 2 - 5 } & PPINAAS & OSES & PPI NAAS & OSES \\
\hline 2018 & 0.57 & -0.47 & 11.9 & 26.6 \\
2019 & -0.06 & 0.48 & 11.9 & 11.7 \\
2020 & -0.49 & -0.01 & 24.9 & 25.3 \\
\hline
\end{tabular}

Note: $d_{k}$ - environmental condition index.

The 2020 weather at the PPI NAAS was extremely unfavorable, which was detrimental to the yield. On the contrary, the 2020 condition index at the OSES was negative, but its absolute magnitude was insignificant. It should be noted that the year condition index differed significantly between the study years. As a result, over the entire study period, at the both trial sites, the accessions were examined both under favorable conditions to reveal the potential yield and under unfavorable ones, which demonstrated adaptive mechanisms of pea.

The yield dynamics illustrated in the graphs fully reflects the effect of the hydrothermal mode on the plant performance and yield (Fig. 1). It should be noted that the yields from the cultivars increased or decreased in parallel with favorable or unfavorable growing conditions. In favorable 2018, the yields from the cultivars did not differ much from those given by breeding lines. However, several accessions showed an interesting individual response. Thus, line SL 10-37 failed to fulfill its potential and gave the lowest yield compared both to the lines and to the cultivars. Lines SL 11-129, SL 11-213, SL 11-166, and SL 11-176 gave highest yields.

Cultivars Haiduk and Oplot gave the highest yields in 2020, which was unfavorable for the growth and development of pea plants, while the other cultivars and lines significantly reduced their yields.

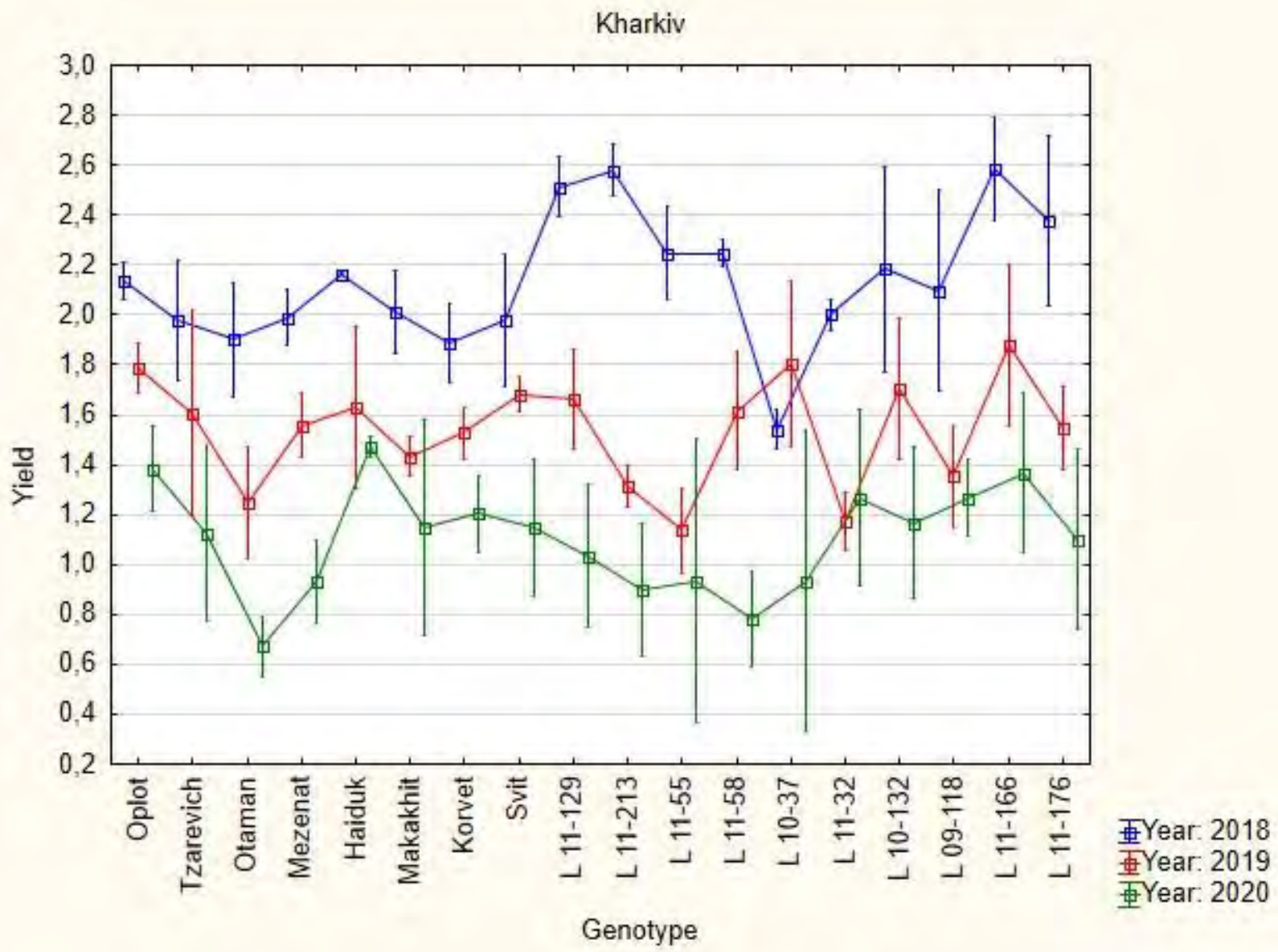

Figure 1. Yield dynamics in the pea breeding accessions in the PPI NAAS conditions. 
At OSES, the yields produced by pea acessions varied significantly from year to year (Fig. $2)$. Even in 2019, which was favorable for pea $\left(d_{k}=0.48\right)$, the yields differed significantly between accessions. The highest yields were received from cv. Haiduk and breeding line SL 11-213. The individual responses of the accessions under the OSES conditions were more contrasting if we compare the yield dynamics with that in the PPI NAAS conditions. Nevertheless, this only confirms the fact that preliminary comprehensive studies, among which environmental trials will be a priority, are mandatoty for the successful introduction of stress-resistant pea cultivars in areas with different hydrothermal modes.

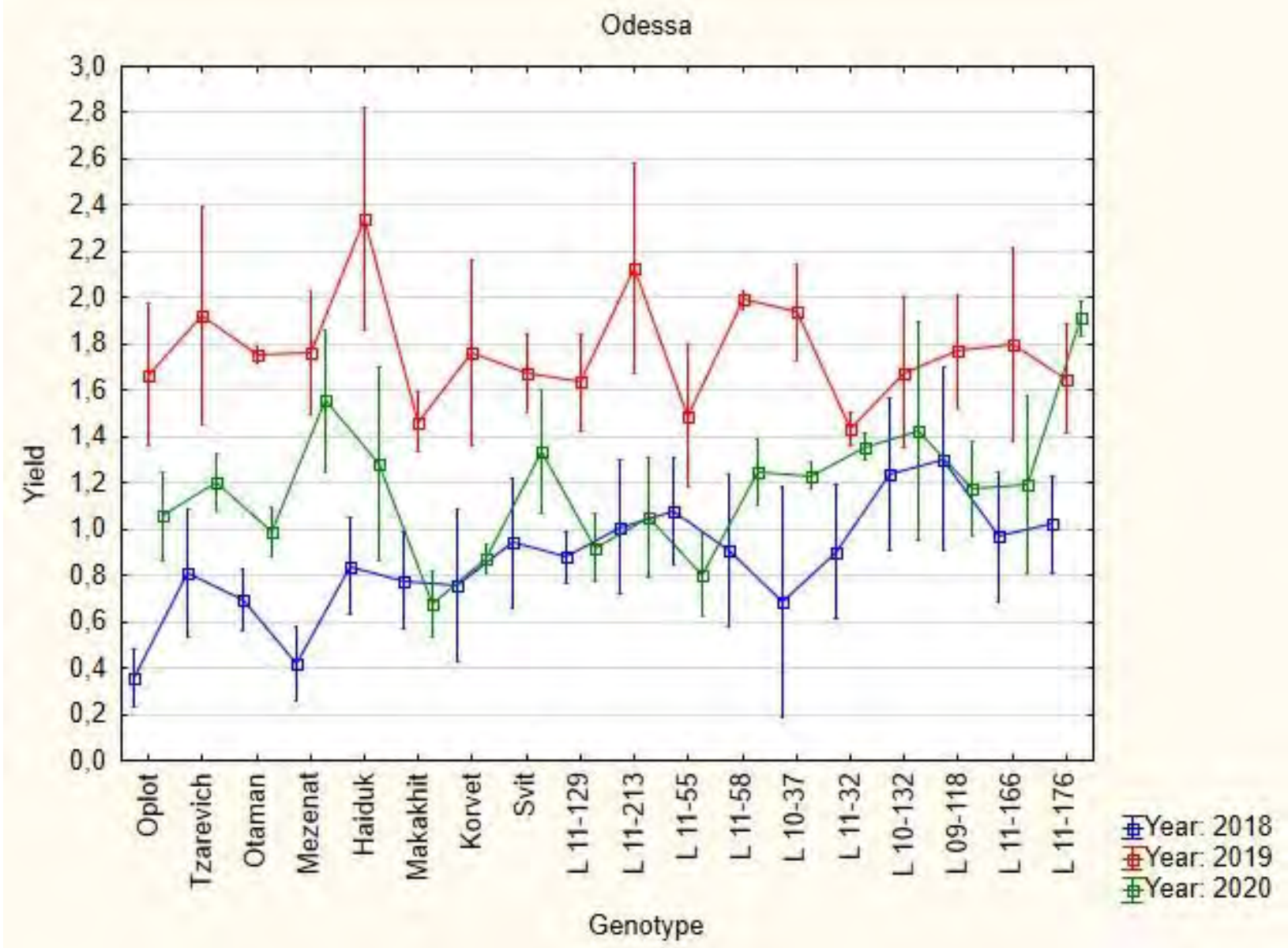

Figure 2. Yield dynamics in the pea breeding accessions in the OSES conditions

The average yield, coefficient of variation, genotypic effect and regression coefficient for the pea accessions are presented in table 2 .

The average yields across the study years at the trial sites were low: $1.59 \mathrm{t} / \mathrm{ha}$ (PPI NAAS) and $1.29 \mathrm{t}$ ha (OSES).

Of the pea cultivars that in the study years gave high yields at the both trial sites, cultivars Haiduk (PPI NAAS - 1.75 t/ha; OSES - 1.36 t/ha) and Svit (PPI NAAS - $1.60 \mathrm{t} / \mathrm{ha}$; OSES - 1.38 t/ha) should be distinguished. In the PPI NAAS conditions, Oplot and Tsarevych also gave high yields (1.76 t/ha and $1.58 \mathrm{t} / \mathrm{ha}$, respectively). However, in the OSES conditions their yields were low. Unlike pea cultivars, the number of lines giving high yields at the PPI NAAS and OSES was greater, namely four breeding lines: SL 11-213, SL 10-132, SL 09-118, and SL 11-176. Line SL 1158 is noteworthy, because in the OSES conditions, in contrast to its performance at the PPI NAAS $(1.55 \mathrm{t} / \mathrm{ha})$, it produced the average yield of $1.48 \mathrm{t} / \mathrm{ha}$, which is the second result after SL 11-176 (1.58 t/ha). In addition, it is more than Svit, which had been created in these conditions) produced. This only emphasizes the fact that, through environmental trials once can keep valuable material and, on its basis, create new cultivars with high economic characteristics. 
It is interesting that the coefficient of variation significantly changes in the cultivars and breeding lines, depending on the trial site. Thus, in the pea cultivars grown at the PPI NAAS, it ranged from $28.3 \%$ (Malakhit) and $21.3 \%$ (Haiduk) to the highest values of $47.7 \%$ (Otaman) and $35.9 \%$ (Metsenat). In the OSES conditions, the coefficient of variation in the cultivars was even higher and ranged $33.6 \%$ to $47.7 \%$.

In contrast to the cultivars in the OSES conditions, the coefficient of variation in the breeding lines was much lower, with some exceptions. For example, in lines SL 11-213 and SL 1037 , it was $35.6 \%$ and $37.1 \%$, respectively; in the other lines, it ranged $11.3 \%$ to $29.0 \%$.

The average coefficient of variation at the trial points was not high: in the PPI NAAS and OSES conditions, it was $9.7 \%$ and $11.7 \%$, respectively, indicating that the accessions tested at the PPI NAAS responded to changes in the growing conditions ipsidirectionally, while at OSES the accessions' response to changes in the growing conditions was more conspicuous.

When comparing the genotypic effect between the cultivars and breeding lines in the PPI NAAS and OSES conditions, we could distinguish cultivar Haiduk and breeding line SL 10-132, as the genotypic effect in these accessions was positive and high at the both study sites.

Table 2

Average yield, genotypic effect (GE) and regression coefficient (RC) in the pea accessions in the environmental trial, 2018-2020

\begin{tabular}{ccccccccc}
\hline & \multicolumn{2}{c}{ Average } & \multicolumn{2}{c}{ V, $\%$} & \multicolumn{2}{c}{ GE* } \\
\cline { 2 - 8 } Accession & PPI & OSES & PPI NAAS & OSES & PPI NAAS & OSESC & PPI NAAS & OSESC \\
& NAAS & & & & & & & \\
\hline Oplot & 1.76 & 1.08 & 21.6 & 43.1 & 0.17 & -0.21 & 0.7 & 1.2 \\
Tsarevych & 1.58 & 1.33 & 27.4 & 33.6 & -0.01 & 0.04 & 0.8 & 1.2 \\
Otaman & 1.29 & 1.16 & 47.7 & 37.8 & -0.30 & -0.13 & 1.2 & 1.2 \\
Metsenat & 1.48 & 1.23 & 35.9 & 44.3 & -0.11 & -0.06 & 1.0 & 1.4 \\
Haiduk & 1.75 & 1.36 & 21.3 & 47.7 & 0.16 & 0.07 & 0.7 & 1.6 \\
Korvet & 1.53 & 1.16 & 22.6 & 39.5 & -0.06 & -0.13 & 0.7 & 1.2 \\
Malakhit & 1.54 & 0.98 & 28.3 & 37.5 & -0.05 & -0.31 & 0.8 & 0.9 \\
Svit & 1.60 & 1.38 & 26.2 & 22.9 & 0.01 & 0.09 & 0.8 & 0.8 \\
SL 11-129 & 1.70 & 1.17 & 46.0 & 24.5 & 0.11 & -0.12 & 1.5 & 0.7 \\
SL11-213 & 1.63 & 1.45 & 52.1 & 35.6 & 0.04 & 0.16 & 1.6 & 1.4 \\
SL 11-55 & 1.46 & 1.17 & 47.2 & 20.7 & -0.13 & -0.12 & 1.3 & 0.5 \\
SL 11-58 & 1.55 & 1.48 & 49.1 & 29.0 & -0.04 & 0.19 & 1.4 & 1.2 \\
SL 10-37 & 1.37 & 1.30 & 34.9 & 37.1 & -0.22 & 0.01 & 0.6 & 1.3 \\
SL 11-32 & 1.47 & 1.30 & 31.4 & 21.8 & -0.12 & 0.01 & 0.8 & 0.6 \\
SL 10-132 & 1.69 & 1.42 & 28.1 & 11.3 & 0.10 & 0.13 & 0.9 & 0.4 \\
SL 09-118 & 1.58 & 1.36 & 28.5 & 23.7 & -0.01 & 0.07 & 0.8 & 0.9 \\
SL 11-166 & 1.95 & 1.30 & 30.8 & 24.8 & 0.36 & 0.01 & 1.2 & 0.9 \\
SL 11-176 & 1.67 & 1.58 & 38.0 & 23.8 & 0.08 & 0.29 & 1.2 & 0.8 \\
\hline Mean & 1.59 & 1.29 & - & - & - & - & - & - \\
\hline V,\% & 9.7 & 11.7 & - & - & - & - & - & - \\
\hline
\end{tabular}

The genotypic effect in breeding lines SL 11-213 and SL 11-176 was also high at the two sites, but its value was higher at OSES. Two more lines, SL 11-58 and SL 09-118, only surpassed the aversge value at OSES. The genotypic effect in breeding line SL 11-166 was the highest (0.36) only in the PPI NAAS conditions. Under the same conditions, the high genotypic effect was observed in cultivar Oplot (0.17).

Thus, of the breeding lines tested in the environmental trial, accessions fulfilling their potential performace both in the PPI NAAS and in OSES conditions were selected.

Over the study period, the regression coefficient in the accessions under investigation ranged 0.4 to 1.6. At the same time, it remained unchanged in cultivars Otaman and Svit; there was slight 
differences between the trial sites in cultivar Malakhit and breeding lines SL 11-213, SL 11-58, SL 11-32, and SL 09-118. In the other samples, the regression coefficient differed significantly between the trial sites.

Thus, comparing the regression coefficient in pea cultivars Oplot, Tsarevych, Haiduk, Korvet, and Metsenat, we could conclude that these accessions were highly intensive in the OSES conditions and extensive in the PPI NAAS conditions (except for Metsenat). Regarding the regression coefficient in the breeding lines, none of them had a regression coefficient of 1.0. Over the study period, the regression coefficient was 1.4 only in line SL 11-58 (PPI NAAS) and 1.2 (OSES), characterizing this line as intensive regardless of the place of cultivation.

Taking into account that the regression coefficient values of $<1$ are intrinsic to extensive accessions, lines SL 10-132 $(\mathrm{RC}=0.4)$ and SL 11-176 $(\mathrm{RC}=0.8)$ are preferred. Because these accessions also have a high genotypic effect. In addition, the regression coefficient in breeding line SL 09-118 was 0.9, with a genotypic effect of 0.07. Such combination of the indicators characterizes the line as relatively stable, with sufficient potential performance, and this breeding line will not be demanding to growing conditions similar to the OSES ones.

Conclusions. Thus, the evaluation of both cultivars and breeding lines in the environmental trial showed that the pea breeding at the Plant Production Institute named after VYa Yuryev had a significant potential to create cultivars that would be well-adapted to both eastern and southern conditions, and that environmental trials remained an effective tool for assessing breeding material and selecting accessions with the maximum fulfillment of the genetic potential.

\section{Список літературних джерел.}

1. Скорина В.В. Оценка среды как фона отбора в Государственном сортоиспытании овощных культур. URL: https://rep.polessu.by/bitstream/123456789/7951/1/7.pdf.

2. Шектыбаева Г.Х., Макарова Г.С., Лиманская В.Б. Результаты экологического сортоиспытания яровой пшеницы в засушливых условиях западного Казахстана. Известия Самарского научного центра Российской академии наук. 2018. Т. 20. № 2(2). С. 254-259.

3. Децына А.А., Илларионова И.В. Экологическое испытание новых сортов подсолнечника селекции ВНИИМК. Масличные культурыл. 2019. № 2(178). С. 22-26. DOI 10.25230/2412608X-2019-2-178-22-26.

4. Тукульбаєва С.А., Васин В.Г., Сидорик И.В. Результаты экологического испытания сортов ярового рапса отечественной и зарубежной селекции в условиях северного Казахстана. DOI: 10.17238/issn2071-2243.2016.2.50.

5. Сидорик И.В., Шугуров И.М., Слабуш В.И., Мельников В.А. Экологическое сортоиспытание сои. URL: https://zarechnoe.ucoz.kz/publ/ehkologicheskoe_sortoispytanie_soi/1-1-0-58.

6. Тохетова Л.А., Абжалелов Б.Б., Кужамбердиева С.Ж., Бекова М.К., Демесинова А.А. Результаты экологического сортоиспытания ярового ячменя в рисовом севообороте Кызылординской области. URL: http:/www.expeducation.ru/ru/article/view?id=9918.

7. Гольдварг Б.А., Боктаев М.В., Филиппов Е.Г., Донцова А.А. Экологическое испытание сортов озимого ячменя в условиях Республики Калмыкия. Зерновое хозяйство России. 2020. № 3(69). С. 48-51.

8. Результаты экологического испытания и отбор перспективных селекционных образцов URL: $\quad$ https://www.vniikormov.ru/ekologicheskaia-selektciia-i-semenovodstvo-kleveralugovogo-klevera-krasnogo/ekologicheskaia-selektciia-i-semenovodstvo-klevera-lugovogoklevera-krasnogo-56.php.

9. Мамеев В.В. Оценка параметров пластичности сортов озимой пшеницы в зависимости от погодных условий Юго-Западной части центра России. Плодоводство и ягодоводство России. 2017. Т. 38. С. 165-169.

10. Константинова О.Б., Кондратенко Е.П. Экологическая пластичность и стабыльность нових сортов озимого тритикале. Вестник НГАУ. Агрономия, лесное хозяйство. 2015. № 3(36). 13-18. 
11. Шакирзянова М.С. Продуктивность и экологическая пластичность сортов гороха экологического сортоиспытания. Достижения науки и техники АПК. 2016. № 30(12). С. $28-30$.

12. Зінченко О.С., Ведмедєва К.В., Якубенко О.В. Пластичність, стабільність та мінливість сортів сої за господарсько-цінними ознаками к екологічному сортовипробуванні. Науково-технічний бюлетень Інституту олійних культур НААН. 2018. № 25. С. 50-60.

13. Доспехов Б.А. Методика полевого опыта: монография. Москва: Колос, 1979. 423 с.

14. Методические рекомендации по экологическому сортоиспытанию кукурузы. Харьков: УкрНИИРСиГ, 1981. $31 \mathrm{c.}$

15. Кильчевский А.В., Хотилева Л.В. Генотип и среда в селекции растений. Мн.: Наука и техника, 1989. $191 \mathrm{c.}$

\section{References}

1. Skorina VV. Evaluation of the environment as a background for selection in the State variety trials of vegetabls. URL: https://rep.polessu.by/bitstream/123456789/7951/1/7.pdf.

2. Shektybaieva GKh, Makarova GS, Limanskaia VB. Results of an environmental trial of spring wheat in arid conditions of western Kazakhstan. Izviestija Samarskogo nauchnogo tsentra Rossijskoy akademii nauk. 2018; 20(2-2): 254-259.

3. Detsyna AA, Ollarionova IV. Environmental trial of new sunflower varieties bred at the AllRussian Research Institute of Oil Crops. Maslichnyie kultury. 2019; 2(178): 22-26. DOI 10.25230/2412-608X-2019-2-178-22-26.

4. Tukulbaieva SA, Vasin VG, Sidorik IV. Results of an envrironmental trial of domestic and foreign spring rapeseed varieties in northern Kazakhstan. DOI: 10.17238/issn20712243.2016.2.50.

5. Sidorik IV, Shugurov IM, Slabush VI, Melnikov VA. Environmental trial of soybean. URL: https://zarechnoe.ucoz.kz/publ/ehkologicheskoe_sortoispytanie_soi/1-1-0-58.

6. Tokhetova LA, Abzhalelov BB, Kuzhamberdieva SZh, Bekova MK, Demesinova AA. Results of an environmental trial of spring barley in a rice crop rotation of the Kyzylorda region. URL: http://www.expeducation.ru/ru/article/view?id=9918.

7. Goldvarg BA, Boktaiev MV, Filippov EG, Dontsova AA. Environmental trial of winter barley varieties in the Republic of Kalmykia. Zernovoie khoziaystvo Rossii. 2020; 3(69): 48-51.

8. Results of environmental trials and selection of promising breeding accessions. URL: https://www.vniikormov.ru/ekologicheskaia-selektciia-i-semenovodstvo-klevera-lugovogo-

klevera-krasnogo/ekologicheskaia-selektciia-i-semenovodstvo-klevera-lugovogo-kleverakrasnogo-56.php.

9. Mamieev VV. Assessment of the plasticity parameters in winter wheat varieties depending on weather conditions in the south-western part of centeral Russia. Plodovodstvo I Yagodovodstvo Rossii. 2017; 38: 165-169.

10. Konstantinova OB, Kondratenko EP. Environmental plasticity and stability of new winter triticale varieties. Vestnik NGAU. Agronomiya, lesnoie khoziaystvo. 2015; 3(36): 13-18.

11. Shakirzianova MS. Performance and environmental plasticity of pea varieties in an environmental trial. Dostizheniia nauki I tekhniki APK. 2016; 30(12): 28-30.

12. Zinchenko OS, Vedmedieva KV, Yakubenko OV. Plasticity, stability and variability of soybean varieties for the economically valuable characteristics in environmental trials. Naukovotekhnichnyi biuleten Instytutu oliynykh kultur. 2018; 25: 50-60.

13. Dospekhov BA. Methods of field experience. Moscow: Kolos, 1979. 423 p.

14. Guidelines on environmental trials of corn. Kharkiv: UkrNIIRSiG, 1981. 31 p.

15. Kilchevskiy AV, Khotyliova LV. Genotype and environment in plant breeding. Minsk: Nauka I tekhnika, 1989. $191 \mathrm{p}$. 


\section{ЕКОЛОГІЧНЕ ВИПРОБУВАННЯ СЕЛЕКЦИЙНИХ ЗРАЗКІВ ГОРОХУ}

Шевченко Л.Н. ${ }^{1}$, Василенко А.О. ${ }^{1}$, Січкар В.І. ${ }^{2}$, Вус Н.О. ${ }^{3,}$ Безуглий I.M. ${ }^{1}$, Соломонов Р.В. ${ }^{2}$, Штельма А.M. ${ }^{1}$, Глянцев А.В. ${ }^{1}$

${ }^{1}$ Інститут рослинництва ім. В. Я. Юр'єва НААН, Україна

${ }^{2}$ Одеська державна дослідна станція НААН,Україна

${ }^{3}$ Харківський національний університет ім. В.Н. Каразіна, Україна

Мета дослідження полягала у встановленні інформативності i адекватності точок екологічного випробування селекційного матеріалу гороху та виділення «ідеального» генотипу.

Матеріали і методи. Селекційний матеріал у досліді представлений сортами селекції IP ім. В.Я. Юр'єва - Царевич, Оплот, Отаман, Меценат, Корвет, Гайдук, Малахіт та десятьма селекційними лініями СЛ 11-129, СЛ 11-213, СЛ 11-55, СЛ 11-58, СЛ 10-37, СЛ 11-32, СЛ 10-132, СЛ 09-118, СЛ 11-166, СЛ 11-176 та селекції Селекційно-генетичного інституту сорт гороху Світ. Всі сорти безлисточкового типу, напівкарликові, середньостиглі, окрім сорту Царевич (середньоранній). Польові досліди проведено у відповідності до методики польового досліду з застосуванням загальноприйнятої технології вирощування гороху.

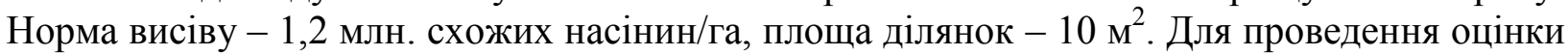
зразків за мінливістю вирощування у різних середовищах використовували регресійну модель, розроблену за методикою S.A. Eberhart, W.A. Russel, де рівень коефіцієнту регресії є показником взаємодії генотип-середа.

Обговорення результатів. В умовах IP НАAН рівень урожайності сортів у сприятливому 2018 році не мав великої різниці у порівнянні із рівнем урожайності селекційних ліній. Найвищу урожайність показали селекційні лінії СЛ 11-129, СЛ 11-213, СЛ 11-166 та СЛ 11-176. Урожайність сорту Гайдук і сорту Оплот у несприятливому для росту і розвитку рослин гороху 2020 році, виявилася найвищою, а всі інші сорті і лінії значно зменшили свій рівень урожайності. В умовах ОДДС навіть у сприятливому для гороху 2019 році рівень урожайності між зразками суттєво відрізнявся, а найвищої значення було у сорту Гайдук та селекційної лінії СЛ 11-213. Індивідуальна реакція зразків за умов вирощування у ОДДС була більш значною у порівнянні із показниками «урожайність» в умовах IP НААН. Тому для успішного впровадження у виробництво в зонах 3 різним гідротермічним режимом стійких до стресових умов сортів гороху необхідним $\epsilon$ попередне екологічне випробування. Високий рівень урожайності як у IP НАAН, так і в ОДДС був лише у чотирьох селекційних ліній: СЛ 11-213 (1,63 т/га та 1,45 т/га), СЛ 10132 (1,69 т/га та 1,42 т/га), СЛ 09-118 (1,58 т/га та 1,36 т/га) та СЛ 11-176 (1,67 т/га та 1,58 т/га). Це лише підкреслює те, що завдяки екологічному випробуванню можна зберегти цінний матеріал і на його основі створювати нові сорти із високими показниками господарських ознак. Цікавим виявився факт значної зміни рівня коефіцієнту варіювання у сортів і селекційних ліній в залежності від місця випробування. Так, в умовах IP НААН він становив від 47,7\% до 21,3\%, а в умовах ОДДС від $33,6 \%$ до 47,7\%. На відміну від сортів в умовах ОДДС показники коефіцієнту варіації селекційних ліній були значно меншим і становив від 11,3\% до 29,0\%, за виключенням селекційних ліній СЛ 11-213 та СЛ 10-37 де його значення було 35,6\% та 37,1\% відповідно. При порівнянні показників генотипового ефекту серед сортів і селекційних ліній в умовах IP НАAН та ОДДС, ми можемо виділити сорт Гайдук і селекційну лінію СЛ 10-132 генотиповий ефект яких в обох точках дослідження мав високі значення. Коефіцієнт регресії досліджуваних зразків коливався від 0,4 до 1,6. При цьому незмінним незалежно від точки випробування він залишився лише у сортів Отаман $(1,2)$ та Світ $(0,8)$. У всіх інших зразків показник коефіцієнту регресії значно різнився.

Висновки. Таким чином проведена оцінка як сортів, так і селекційних ліній у екологічному випробуванні показала що селекція гороху в Інституті рослинництва імені В.Я. Юр'єва має значний потенціал для створення сортів добре пристосованих як для умов східної частини, так і для умов Півдня, а екологічне випробування залишається дієвим інструментом для 
оцінки створеного селекційного матеріалу і добору зразків з максимальним рівнем реалізації генетичного потенціалу за конкретним комплексом чинників довкілля.

Ключові слова: горох, сорти, урожайність, екологічне випробування, генотиповий ефект, коефіиієнт регресії, стабільність.

\section{ЭКОЛОГИЧЕСКОЕ ИСПЫТАНИЕ СЕЛЕКЦИОННЫХ ОБРАЗЦОВ ГОРОХА}

Шевченко Л.Н. ${ }^{1}$, Василенко А.А. ${ }^{1}$, Сичкарь В.И. ${ }^{2}$, Вус Н.А. ${ }^{3}$, Безуглый И.Н. ${ }^{1}$, Соломонов Р.В. ${ }^{2}$, Штельма А.М. ${ }^{1}$, Глянцев А.В. ${ }^{1}$

${ }^{1}$ Институт растениеводства имени В. Я. Юрьева НААН, Украина

${ }^{2}$ Одесская государственная опытная станция НААН, Украина

${ }^{3}$ Харьковский национальный университет имени В.Н. Каразина, Украина

Цель исследования состояла в определении информативности и адекватности точек экологического испытания селекционного материала гороха и выделение «идеального» генотипа.

Материалы и методы. Селекционный материал в опыте представлен сортами селекции Института растениеводства им. В. Я. Юрьева (ИР НААН) - Царевич, Оплот, Отаман, Меценат, Корвет, Гайдук, Малахіт и десятью селекционными линиями СЛ 11-129, СЛ 11-213, СЛ 11-55, СЛ 11-58, СЛ 10-37, СЛ 11-32, СЛ 10-132, СЛ 09-118, СЛ 11-166, СЛ 11-176 и Селекционно-генетического институга сорт Світ. Все сорта безлисточковые (усатые), полукарликовые, среднеспелые, кроме сорта Царевич (среднеранний). Полевые опыты проведены в ИР НААН и на Одесской государственной сельскохозяйственной опытной станции НААН (ОГСОС) в соответствии с методикой полевого эксперимента с использованием общепринятой технологии выращивания гороха. Норма высева 1,2 млн. всхожих семян на гектар, площадь делянок $-10 \mathrm{~m}^{2}$. Для проведения оценок образцов в изменчивых условиях выращивания в разных средах использовали регрессионную модель, методически разработанную S.A.Eberhart, W.A. Russel, где показатель регрессии является показателем взаимодействия генотип-среда.

Обсуждение результатов. В условиях ИР НААН уровень урожайности сортов в благоприятных условиях для роста и развития растений гороха 2018 г. практически не отличался от селекционных линий. Наивысшую урожайность показали селекционные линии СЛ 11-129, СЛ 11-213, СЛ 11-166 и СЛ 11-176. В 2020 году, когда условия вегетационного периода не дали растениям проявить свой потенциал, только сорта Гайдук и Оплот, по сравнению со всем набором образцов, показали достаточный уровень урожайности. В условиях ОГСОС в благоприятном 2019 году разность по уровню урожайности между образцами была очень существенной, с наибольшими показателями у сортов Гайдук и селекционной линии СЛ 11-213. За годы испытания индивидуальная реакция образцов на выращивание в точке ОГСОС была более контрастной по сравнению с показателями урожайности в ИР НААН. Поэтому для успешного внедрения в производство в зонах с различным гидротермическим режимом устойчивых к стрессовым условиям сортов гороха необходимым становится предварительное всестороннее изучение, среди которого экологическое испытание будет занимать приоритетное место. Высокий уровень урожайности как в ИР НААН, так и в ОГСОС был только у четырех селекционных линий: СЛ 11-213 (1,63 т/га и 1,45 т/га), СЛ 10-132 (1,69 т/га и 1,42 т/га), СЛ 09-118 (1,58 т/га и 1,36 т/га) и СЛ 11-176 (1,67 т/га и 1,58 т/га). Таким образом, проведение экологического испытания позволило сохранить ценный материал и выделить перспективные линии, а лучшие образцы использовать в перспективе как исходный материал для селекции. Интересным был факт изменчивости коэффициента вариации у сортов и селекционных линий в зависимости от места испытания. В условиях ИР НААН для сортов его значение было от $21,3 \%$ до 47,7\%, а в ОГСОС - от 22,9\% до 47,7\%. Для селекционных линий в условиях ИР НААН значение коэффициента было от $28,1 \%$ до $52,1 \%$, а в ОГСОС от $11,3 \%$ до 29,0\% за исключением линий СЛ 11-213 и СЛ 10-37, у которых он составил 35,6\% и 37,1\% соответственно. При сравнении показателей генотипического эффекта по результатам испытания в ИР НААН и ОГСОС выделены сорт Гайдук и селекционная линия СЛ 10-132, у которых уровни показателя были высокими в обеих точках испытания. Значение коэффициента регрессии исследуемых образцов составил от 0,4 до 1,6. При этом, независимо от точки испытания, он оставался стабильным только у сортов Отаман и Світ, а у остальных образцов значительно изменялся.

Выводы. Таким образом, проведенная оценка сортов и селекционных линий в экологическом 
испытании показала, что селекция гороха в Институге растениеводства им. В.Я. Юрьева имеет значительный потенциал для создания сортов, хорошо приспособленных как для условий Восточной части Украины, так и для условий Юга. Экологическое испытание остается действенным инструментом для оценки созданного селекционного материала и отбора образцов с максимальным уровнем реализации генетического потенциала в конкретных комплексах условий выращивания.

Ключевые слова: горох, сорт, урожайность, экологическое испытание, генотипический эффект, коэффициент регрессии, стабильность.

\section{ENVIRONMENTAL TRIAL OF PEA BREEDING ACESSIONS}

Shevchenko L.M. ${ }^{1}$, Vasylenko A.O. ${ }^{1}$, Sichkar V.I. ${ }^{2}$, Vus N.O. ${ }^{3}$, Bezuglyi I.M. ${ }^{1}$, Solomonov R.V. ${ }^{2}$, Shtelma A.M. ${ }^{1}$, Glyantsev A.V. ${ }^{1}$

${ }^{1}$ Plant Production Institute named after V.Ya. Yuriev of NAAN, Ukraine

${ }^{2}$ Odesa State Agricultural Research Station, Ukraine

${ }^{3}$ Kharkiv National University nd a V.N. Karazin, Ukraine

The aim of the study was to determine the information content and adequacy of the ecological testing points of the pea breeding material and to identify the "ideal" genotype.

Materials and methods. The breeding material in the experiments was represented by cultivars bred at the PPI nd.a. V.Ya. Yuriev (Tsarevych, Oplot, Otaman, Metsenat, Korvet, Haiduk, and Malakhit) and ten breeding lines (SL 11-129, SL 11-213, SL 11-55, SL 11-58, SL 10-37, SL 11 32, SL 10-132, SL 09-118, SL 11-166, and SL 11-176). In addition there was one cultivar (Svit) bred at the Plant Breeding and Genetics Institute. All the cultivars are leafless, semi-dwarf, midripening, except for Tsarevych (mid-early). The field experiments were carried out in accordance with the methods of field experimentation, using the conventional pea growing technology. The seeding rate was 1.2 million germinable seeds/ha; the plot area was $10 \mathrm{~m}^{2}$. To evaluate the accessions for the variability in different environments, we used a regression model developed by S.A. Eberhart and W.A. Russel, where the regression coefficient is an indicator of the genotype-environment interaction. This model is included in "Guidelines for Environmental Trials of Corn".

Results and discussion. Thus, comparing the regression coefficient in pea cultivars Oplot, Tsarevych, Haiduk, Korvet, and Metsenat, we could conclude that these accessions were highly intensive in the OSES conditions and extensive in the PPI NAAS conditions (except for Metsenat). Regarding the regression coefficient in the breeding lines, none of them had a regression coefficient of 1.0. Over the study period, the regression coefficient was 1.4 only in line SL 11-58 (PPI NAAS) and 1.2 (OSES), characterizing this line as intensive regardless of the place of cultivation.

Taking into account that the regression coefficient values of $<1$ are intrinsic to extensive accessions, lines SL 10-132 $(\mathrm{RC}=0.4)$ and SL 11-176 $(\mathrm{RC}=0.8)$ are preferred. Because these accessions also have a high genotypic effect. In addition, the regression coefficient in breeding line SL 09118 was 0.9 , with a genotypic effect of 0.07 . Such combination of the indicators characterizes the line as relatively stable, with sufficient potential performance, and this breeding line will not be demanding to growing conditions similar to the OSES ones.

Conclusions. Thus, the evaluation of both cultivars and breeding lines in the environmental trial showed that the pea breeding at the Plant Production Institute named after VYa Yuryev had a significant potential to create cultivars that would be well-adapted to both eastern and southern conditions, and that environmental trials remained an effective tool for assessing breeding material and selecting accessions with the maximum fulfillment of the genetic potential.

Key words: pea, variety, yield, environmental testing, genotypic effect, regression coefficient, stability 